\title{
The Role of Faculty Members in Developing the Patriotism amongst Their Students at Jadara University and Jerash Al Ahlia University from the Students' Point of View
}

\author{
Hazem Badarneh",", Najwa Darawsha ${ }^{2}$, Ahmed AL-Shoha ${ }^{3}$, Mareem Abdel Aal ${ }^{4}$ \\ ${ }^{1}$ Department of Social Science, Faculty of Science and Arts, Jordan University of Science and Technology (JUST), Jordan \\ ${ }^{2}$ Department of Educational Administration, Faculty of Educational Sciences, Jadara University, Jordan \\ ${ }^{3}$ Irbid Model School, Irbid Directorate of Education, Jordan \\ ${ }^{4}$ Al Ramtha School, Al Ramtha Directorate of Education, Jordan
}

Received June 4, 2020; Revised July 17, 2020; Accepted August 10, 2020

\section{Cite This Paper in the following Citation Styles}

(a): [1] Hazem Badarneh, Najwa Darawsha, Ahmed AL-Shoha, Mareem Abdel Aal, "The Role of Faculty Members in Developing the Patriotism amongst Their Students at Jadara University and Jerash Al Ahlia University from the Students' Point of View," Universal Journal of Educational Research, Vol. 8, No. 10, pp. 4478-4489, 2020. DOI: 10.13189/ujer.2020.081015.

(b): Hazem Badarneh, Najwa Darawsha, Ahmed AL-Shoha, Mareem Abdel Aal (2020). The Role of Faculty Members in Developing the Patriotism amongst Their Students at Jadara University and Jerash Al Ahlia University from the Students' Point of View. Universal Journal of Educational Research, 8(10), 4478-4489. DOI: 10.13189/ujer.2020.081015.

Copyright $\bigcirc 2020$ by authors, all rights reserved. Authors agree that this article remains permanently open access under the terms of the Creative Commons Attribution License 4.0 International License

\begin{abstract}
This study aimed at identifying the role of faculty members in developing a sense of patriotism amongst students at Jadara University and Jerash Al Ahlia from the students' point of view. The researchers adopted a descriptive approach. A questionnaire was used as a study tool. The study sample consisted of (707) students from both universities. The results showed that the faculty members had a very high significant role in developing a sense of patriotism among their students. The results also showed that there were differences attributable to (the gender, university, and college variable) and that there were also differences attributable to the variable "year of study" which came in favor of the second, third, and fourth year. Based on the results of the study, the researchers recommended enhancing the role of the faculty member in developing students' awareness of the importance of the sense of patriotism and its positive role on the security and stability of their nation and motivating students to adhere to financial obligations towards their country and its prosperity.
\end{abstract}

Keywords Role, Patriotism, Faculty Members, Jadara
University, Jerash Al Ahlia University

\section{Introduction}

The development of the patriotism sense among individuals is achieved through formal and informal education, direct and indirect ways, and through the family, school, university, work environment, and others. Universities are among the most important educational institutions that play a significant role in building and developing the national sense among students because students at this stage are the main tools of community development and maintenance. Undoubtedly, universities can enhance the national sense of their students through multiple means the most important of which is its faculty members, activities, and the education process.

The love of the country and seeking its development is clear evidence of the sincere national sense, and the best example of this is seen in the behavior of the prophet of Allah when he prayed for blessing the city "Medina", and 
blessing its fruit, as Abu Huraira, may God be pleased with him said that the Messenger of Allah, may Allah bless him, said, 'O Allah! Bless us in our fruits. Bless us in our city. Bless us in our sa and bless us in our mud. O, Allah! Ibrahim is Your slave, Your Khalil, and Your Prophet. I am Your slave and Your Prophet. He prayed to You for Makka. I pray to You for Madina for the like of what He prayed to You for Makka, and the like of it with it.' Then he called the smallest child he saw and gave him the fruits [1].

The issue of the sense of patriotism and belonging received great attention from interested and specialized people who seek to preserve the youth's thought and enhance their national identity, especially in light of the great technical development the world is experiencing, and under the domination of globalization in all sectors such as economic, social, media and political [2].

Al-Enzi [3] stated that the issue of patriotism and citizenship is one of the most important issues that concern educators because it focuses on a student's relationship with his nation and its issues and his positive interaction towards it, especially in light of political changes, and to remove barriers between cultures and ideas, which requires educational institutions to promote students' patriotism to their nation, their identity pride, and their fortification of destructive ideas.

Batha [4] believed that national sense is an important demand for the individual, which arises from his interaction with his society through a set of attitudes and values that determine his behavior and fulfill his needs. Every person is subject to the obligations of his society therefore he must bear his responsibilities, feels justice, love, and work hard. The development of the national sense and implanting it among the members of society leads to respecting the rights of their homeland and realizing their rights and duties. Developing a sense of belonging among individuals in a society leads to the emergence of good citizenship through which they defend the unity and cohesion of their society [5].

National sense is the emotional bonds between a person and his homeland, and it reflects the positive values and feelings of love towards the people and the land. National sense also expresses a group of feelings that address loyalty, love, commitment, care, pride, and dedication, and it contributes to achieving national unity, participation in public life, and achieving the welfare of the country and citizens.

Mohammad [6] stated that patriotism will not be achieved unless there is a national sense among the individuals, concerning about the issues of their country, preserving national independence, building a sense of loyalty and belonging to young generations, pride in the homeland, good citizenship, desire for political participation, and raising the value of citizenship. The individual's enjoyment of the national sense enables him to actively participate in the service of society and achieve his goals, in addition to the development of the national sense that contributes to forming a belonging citizen who preserves the economic and social capabilities of his country, and enables him to spread the culture of his country among different nations [7]

The national sense appears through sharing the same destiny and contributing to the development of humanity. It includes knowledge of customs, traditions, choices, and beliefs. It requires a commitment to the duties arising from knowledge and understanding of life events, and the ability to distinguish between possible trends in which individuals live through this awareness [8].

It is defined as a set of positive emotions the individual holds towards his homeland, and it includes the feeling of belonging, citizenship, and a sense of social responsibility towards community service and national participation[7] The national sense refers to the individual belonging to his nation and country, and this feeling includes dimensions such as past experiences, current perceptions, and future expectations [9].

The national sense includes two main dimensions blind patriotism, which represents a kind of dependence which based on adopting state ideas and policies without discussing them, and constructive patriotism that is based on the discussion of policies and ideas for developing them in a way that achieves national goals, community values, and human values [10].

Mohd \& Rohani [11] specified a set of factors that affect enhancing students' national sense: belief in God, faith in society and its values, loyalty and belonging, respect for the constitution and rule of law, social responsibility, and defense of the country. On the importance of patriotism [12] pointed out that developing patriotism encourages future thinking and planning, which is the key to preserving the identity and helps to raise the level of mental health of the individual, feeling satisfied with society and feeling happy.

University education bears a great responsibility in preserving the permanence of society and its progress, by preserving the community's values, culture, customs and traditions, and its value system. The main element that plays a role in shaping the national sense is the university professor, who has a high value in society.

Al-Shammari [13] pointed out that the faculty members have a significant role in developing students' values through the faculty member fairness to students when discussing issues with them, and when the faculty member is not biased towards certain groups of students, and through the faculty member's keenness to achieve justice between Students.

Quinn [14] revealed that the university's role in national belonging is achieved by creating a suitable learning environment or environment that encourages students to acquire these values. Likewise, national affiliation in universities can be developed by embodying the spirit of cooperation, volunteerism, tolerance, justice, equality, and participation, and before This comes the role of decisions and study plans in developing the values of citizenship, 
including the content of knowledge, attitudes, and trends that contribute greatly to this aspect.

Al-Jazzar [15] pointed out that developing the national sense among students helps them to understand the events well, and develops the national awareness that helps them learn from the past, good use of the experiences of the former, have a sincere sense of belonging to the country, willingly sacrifice for it and make every effort to achieve its advancement. Openness to the world in social, cultural, economic, political, and educational sectors, requires paying more attention to deepening the sense of loyalty towards the country and to instill respect for the system, national trends, and laws [16].

Olsen [17] stated that educational institutions are among the most important institutions that play a prominent role in preserving values, behavior, and ideas, and in developing the national sense through the knowledge, experience, and activities they provide related to the studying courses. He added that the faculty members in universities contribute to developing the national sense among students by spreading the spirit of familiarity and cooperation, instilling the values of national unity in the hearts of students, how to preserve the security and stability of the country, and the capabilities and properties of the country [18].

Al-Khawaldah [19] mentioned that universities' faculty members also contribute to instilling citizenship through instilling the concept of taking responsibility among students, helping them to recognize the issues of the nation, the challenges facing them, developing a sense of loyalty to the country, instilling a love of work, and preserving the achievements of the country.

There are a set of duties assigned to faculty members that develop the national sense among students, including educating students about the difficulties and challenges facing their country, raising their sense of responsibilities in confronting these challenges, seeking positive solutions, informing them of their rights, and duties, developing their ability to interpret current events in the country and having a critical view of what is written by newspapers and magazines [20].To enable a university to play its educational and guiding role in promoting the values of loyalty and belonging among its students, concepts, and basics of homeland sense must be instilled, and here the role of faculty members in Jordanian universities is highlighted in developing the national sense among their students. The following areas must be achieved to ensure that the conditions for the development of the national sense are fulfilled:

The first area: the aesthetic patriotism: it needs to intensify the efforts of faculty members in developing interest in directing students' emotions, enhancing students' preservation of the environment and protecting it from pollution, adherence to public taste in clothing, and appreciation of science and scholars within the country.

The second area: the national cultural sense: students must be directed to appreciate the values of belonging, the heritage, and the civilization of the country. In addition to helping them to open consciously to another culture and benefited from their positive impact, which is reflected in students' thinking in a positive way that enhances his respect for the customs and traditions of society.

The third area: the national social sense: it is achieved by enhancing the participation of students in community volunteer work and making them aware of how to address rumors, and promoting a culture of respect, peaceful coexistence, and tolerance among members of society.

The Fourth area: The national economic sense: educating students to adhere to the financial duties towards the country, its products, its properties, and how to take care of the nation's properties.

\section{Previous Studies}

Several studies addressed the topic of developing the sense of patriotism such as [21] that aimed to identify the role of a faculty member in Jordanian universities in educating students about the dangers of terrorist and extremist thought, and their role in developing their national sense. The descriptive approach was followed using a questionnaire as a study tool. The study sample consisted of (459) students. The results of the study found that the role of the faculty member in Jordanian universities in educating students about the dangers of terrorist and extremist thought, and their role in developing the national sense came to a moderate degree. The result also showed that there were significant differences in student responses due to gender variable and in favor of the male students, and by college variables in favor of human colleges.

Suwaidan, Al-Qaoud, and Obaidat [22] conducted a study aimed at revealing the role of colleges of education in Saudi universities in enhancing the value of citizenship among students from the viewpoint of the faculty members and the students. The descriptive approach was followed by applying a questionnaire to a random sample consisting of (146) faculty members and (545) students. The findings related to the opinions of the faculty members showed that the role of colleges of education in Saudi universities in strengthening citizenship value was high and that there were no differences attributed to the impact of specialization, academic rank, and experience. Where the result according to the students' point of view showed that the role of colleges of education in Saudi universities in promoting the value of citizenship among its students was high, and there were no differences due to the impact of specialization, and the differences were attributed to the academic level and in favor of the third and fourth year.

Nair \& Sinasamy [23] conducted a study aimed at identifying the availability of national sense among middle and high school students in Malaysia through the descriptive approach. To achieve the goal of the study a questionnaire consisting of (40) items was applied to a 
random sample of (120) students. The findings indicated that the students enjoy a great sense of patriotism, and the study showed that citizenship, loyalty, affiliation, and service to the country are the most important manifestations of their patriotic sense, as it was found that there is no difference in the level of patriotism attributable to gender and literary changes.

Ozturk, Malkoc \& Ersoy [24] conducted a study aimed at revealing the availability of national sense in social studies textbooks in Turkey. A qualitative research approach based on qualitative interviews was followed. The sample consisted of (14) teachers from public intermediate and secondary schools were interviewed. The results of the study indicated that the concepts of patriotism such as love, belonging, loyalty, national commitment, and sense of responsibility are available to a moderate degree in the books and that the most available are concepts of democracy and effective citizenship.

Al-Thabiti and Hussein [25] conducted a study aimed at identifying the role of the University of Tabuk in developing the values of citizenship among students, as well as determining whether there were differences in the values of citizenship attributed to variables: the academic level, gender, and specialization. The descriptive approach was followed by applying a questionnaire to (590) male and female students at the headquarters of the University of Tabuk. The study reached several results, the most important of which is the high role that the University of Tabuk played in developing citizenship among the students at Tabuk University. It also showed that the highest characteristic of citizenship was the value of loyalty to the country, followed by adherence to community standards, then the sense of moral responsibility towards society. There were no significant differences in the level of citizenship in general attributed to the variables specialization, gender, or academic level.

Al-Shafi'i, Al-Fatlawi, and Al-Daini [26] conducted a study aimed at identifying the strategies of faculty members in developing the value of citizenship among students at the University of Karbala in Iraq. The descriptive approach was followed by applying a questionnaire consisting of (32) paragraphs to (320) students. The results of the study showed that the degree of teaching staff practice of national sense development strategies was moderate and that there were statistically significant differences in students' responses attributed to gender variable in favor of females.

Al-Khawaldeh [19] conducted a study aimed at identifying the level of the faculty members role in Jordanian universities in developing citizenship values from the students' perspective and identifying the differences in the level of the role according to the variables of the student's gender, university, college, and the level of study. To achieve the objectives of the study a questionnaire consisted of (48) items, it was applied on (928) male and female students at Jordanian universities.
The results of the study showed that the level of the role of the faculty member in developing citizenship value was moderate in general and in all the study areas. The results also showed that there were statistically significant differences attributable to the variables: the gender and in favor of males and the university variable for the benefit of private universities, the variable of colleges for the benefit of human colleges, and the variable of study level in favor of first-year students.

Al-Daw [27] conducted a study aimed at identifying the level of homeland belonging among students in colleges of education at the University of Bakht al-Rida and its relationship to academic achievement. The researcher adopted a descriptive approach. The sample consisted of (146) students. The questionnaire was used as a tool for study. The results indicated that there was a positive level of homeland affiliation among students and that there were no differences in the responses of students by gender variable.

Al-Najjar [18] identified the role of higher education institutions in the Gaza Strip in developing the national sense of its students. He followed the descriptive approach by using a questionnaire. The sample consisted of (880) faculty members. The study found that the role of higher education institutions in the Gaza Strip in developing the national sense of its students from the viewpoint of its faculty members came to a high degree. The results did not show any differences due to gender, years of experience, or college.

Through reviewing the aforementioned studies we realize that they followed the descriptive approach in identifying the roles of universities, colleges of education, and faculty members in practicing and enhancing the values of belonging to the homeland, and in developing the national sense and its values, and the sample of studies varied between students and faculty members. The current study agrees with the general goal of developing the national sense among university students, but it differs in the study tool, its sample, and the place it is conducted in. Researchers have benefited from the previous studies in identifying the study problem, building its tools, and interpreting its results.

\subsection{The Study Problem}

The world is witnessing rapid changes and developments in the fields of economic, cultural, social, educational, and political life, all due to the tremendous developments in the scientific and technological field, which have made the world as one village so that the individual can be informed and interact with all the developments without restrictions. Regardless of the positive effects it brings, various aspects are negatively affected by cultural and intellectual changes, especially on the youth who are considered the bases of any developing society. Conceivably, national sense, citizenship, belonging, and everything related to it are considered 
areas of influence due to cultural intellectual openness among the youth which requires the relentless pursuit of developing the national sense among university education students.

Considering the scarcity of previous studies that dealt with the role of a faculty member in developing the sense of patriotism, and the urgent need for such studies, the problem of this study aimed at identifying the role of faculty members in developing the sense of patriotism amongst students at Jadara University and Jerash Al Ahlia University by answering the following two questions:

1. What is the role of faculty members in developing a sense of patriotism amongst students at Jadara University and Jerash Al Ahlia University from students' point of view?

2. Are there statistically significant differences at the level of significance $(\alpha \leq 0.05)$ between the averages of the responses of the study members about the role of faculty members in developing the sense of patriotism amongst students at Jadara University and Jerash Al Ahlia University from students' point of view attributed to variables: university, gender, school year and the college?

\subsection{Study Objectives}

This study aimed to identify the role of faculty members in developing the sense of patriotism amongst students at Jadara University and Jerash Al Ahlia University and to reveal if there is a statistically significant difference according to the participants' responses on the effect of the role of faculty members in developing the national sense according to variables (University, gender, academic year, and college.)

\subsection{The Importance of the Study}

The importance of this study lies in the subject it addresses and the goals it seeks to achieve. Patriotism is an important subject nowadays as it plays an important role in preserving society and in instilling the national sense among students. As a result of the changes that occurred globally, more effort should be spent to build an interdependent society, demonstrate the negative role of the social media on youth especially the ideas that seek to destroy society and its division, which requires building curricula that enhance community cohesion and inculcate the values and dimensions of their national sense. It is hoped to identify the role of faculty members at Jadara universities and Jerash Al Ahlia University in developing the national sense among students. This study may also contribute to paving the way for specialists and graduate students to carry out studies on developing the national sense among students.

The study terminology: This study adopted the following conventional and procedural definitions:
- Role: The set of tasks, and duties performed by faculty members at Jadara universities and Jerash Al Ahlia.

- National Sense: It is a set of "the positive emotions of an individual towards his homeland, and it includes belonging, citizenship and a sense of social responsibility towards community service and national participation" [7]

- The researchers define as the group of feelings that an individual has towards his homeland, which is: to cherish national symbols, ready to protect his homeland, feel a sense of social responsibility, and do voluntary work and other indicators related to the cultural, social, economic, and aesthetic dimensions. It is measured by the total degree obtained by the responses of the participants in the study after responding to the items of the study tool.

- Faculty Members: Anyone who holds a Ph.D. and works at Jadara University or Jerash Al Ahlia at the scientific and human colleges with scientific ranks: Professor, Associate Professor, and Assistant Professor.

- The limits of the study: This study was limited to the role of faculty members in developing the national sense, in Jadara University and Jerash Al Ahlia for the academic year (2020/2019). As the tool limited this study to students' responses to the items of the tool, which consist of (24) items.

\section{Methods and Procedures}

\subsection{Study Methodology: The Researchers Used the Descriptive Survey Method}

The study sample: The study was applied to a random stratified sample of (800) students in the scientific and human colleges in Jadara universities and Jerash Al Ahlia, (400) male and female students from each university, in the first semester of the 2019/2020 academic year, and (707) questionnaires were for analysis with a retrieval rate (88.4) Table 1 shows the distribution of the study sample according to the independent variables.

Table1. Distribution of the study sample according to the levels of their variables

\begin{tabular}{|c|c|c|c|}
\hline Variables & Categories & No. & percent \\
\hline \multirow{3}{*}{ University } & Jerash Al Ahlia & 378 & $53.5 \%$ \\
\cline { 2 - 4 } & Jadara University & 329 & $46.5 \%$ \\
\hline \multirow{3}{*}{ Gender } & Male & 372 & $52.6 \%$ \\
\cline { 2 - 4 } & Female & 335 & $47.4 \%$ \\
\hline \multirow{3}{*}{ Year of study } & First & 70 & $9.9 \%$ \\
\cline { 2 - 4 } & Second & 183 & $25.9 \%$ \\
\cline { 2 - 4 } & Third & 298 & $42.1 \%$ \\
\hline \multirow{2}{*}{ Collage } & Fourth & 156 & $22.1 \%$ \\
\cline { 2 - 4 } & Scientific & 299 & $42.3 \%$ \\
\hline \multicolumn{2}{|c|}{ Humanities } & 408 & $57.7 \%$ \\
\hline \multirow{2}{*}{ Total } & 707 & $100 \%$ \\
\hline
\end{tabular}




\subsection{Building the Study Tool}

The researchers benefited from the previous studies related to the national sense in developing a tool to measure the role of faculty members at Jadara University and Jerash Al Ahlia in developing the national sense among students from their point of view. It was composed in its initial form of (28) items distributed in four areas: the cultural patriotism, and social patriotism, economic patriotism, and aesthetic patriotism. The 5 - point scale are represented as follows $5=$ very high, $4=$ high, $3=$ moderate, $2=$ low and $1=$ very low.

\subsection{The Validity and Reliability of the Study Tool}

\subsubsection{The face validity}

The face validity of the tool was checked, as it was presented to (11) arbitrators from the academic members of the Jordanian universities, who checked the items of the questionnaire and their appropriateness. The final form of the questionnaire consisted of (30) items.

\subsubsection{Content validity}

The questionnaire was applied to a stratified random sampling of (20) students from the study population. Correlation coefficients were calculated between the scores of each item and the total score of the area it belongs to. Correlation coefficients were also calculated between the score of each area of the questionnaire and the overall degree of the questionnaire as shown in Table 2.

Table 2. Pearson correlation coefficients between the areas of the tool and the overall tool

\begin{tabular}{|c|c|c|}
\hline No. & Areas & Overall tool \\
\hline First & cultural patriotism & $* * .763$ \\
\hline Second & social patriotism & $* * .855$ \\
\hline Third & economic patriotism & $* * .378$ \\
\hline Fourth & Aesthetic patriotism & $* * .846$ \\
\hline
\end{tabular}

Table 2 shows that the values of the coefficients of correlation of the areas of the study tool with the overall tool ranged between $(0.378-0.846)$

\subsubsection{The reliability of the study tool}

Two methods were used to check the reliability of the study tool, the first method is the application of test-retest and the second method is the calculation of the Cronbach coefficient for the questionnaire items. Where in the first the questionnaire a sample of (20) male and female students twice with a period of two weeks was applied to the survey, and the Pearson correlation coefficient (reliability coefficient) was calculated between the two applications. In the second method, the internal consistency coefficient was calculated by the Cronbach alpha coefficient as indicated in Table 3.

Table 3. Coefficient of Test-retest reliability and internal consistency of the Alpha Cronbach for the overall tool and its areas

\begin{tabular}{|c|c|c|c|c|}
\hline No. & Areas & $\begin{array}{c}\text { Internal } \\
\text { consistency }\end{array}$ & Test-retest & $\begin{array}{c}\text { No. } \\
\text { items }\end{array}$ \\
\hline First & $\begin{array}{c}\text { cultural } \\
\text { patriotism }\end{array}$ & 0.87 & 0.90 & 6 \\
\hline Second & $\begin{array}{c}\text { social } \\
\text { patriotism }\end{array}$ & 0.87 & 0.89 & 7 \\
\hline Third & $\begin{array}{c}\text { economic } \\
\text { patriotism }\end{array}$ & 0.90 & 0.89 & 6 \\
\hline Fourth & $\begin{array}{c}\text { Aesthetic } \\
\text { patriotism }\end{array}$ & 0.92 & 0.90 & 5 \\
\hline \multicolumn{2}{|c|}{ Overall tool } & $\mathbf{0 . 9 3}$ & $\mathbf{0 . 9 2}$ & $\mathbf{2 4}$ \\
\hline
\end{tabular}

Table 3 shows that the overall Test-retest score for the responses reached (0.92). The internal consistency coefficient (Cronbach's Alpha) for the overall score is (0.931) which is considered a high degree. Accordingly, these values were considered appropriate for this study.

\subsubsection{The standard for Correcting the Tool}

The statistical model with a relative gradient of 5- point Likert scale was adopted. The statistical standard was adopted using the following equation:

\begin{tabular}{|lllll|}
\hline Very high & High & moderate & Low & Very low \\
$5.00-4.20$ & $4.20-3.40$ & $3.40-2.60$ & $1.80-2.60$ & $1.80-1.00$ \\
\hline
\end{tabular}




\subsubsection{Study variable}

- The dependent variable: The role of faculty members in developing patriotism among the students at Jadara University and Jerash Al Ahlia University from students' point of view.

- Independent Variables: (University: Jadara, and Jerash Al Ahlia) Gender, School Year (First, Second, Third, Fourth), College (Scientific, Humanities).

Statistical treatment: The mean and standard deviations were calculated to answer the first question, while to answer the second question, the MANOVA was used.

\section{Discussion of Result}

The study aimed at identifying the role of faculty members in developing the sense of patriotism amongst the students at Jadara University and Jerash Al Ahlia University. To achieve the study objectives the questions were answered according to its sequences of the results. Results of the first question, which stated: "What is the role of faculty members in developing the sense of patriotism amongst students at Jadara University and Jerash Al Ahlia University from the students' point of view?'To answer this question, overall means and standard deviations were calculated for the responses of the participants on the items, and each of its areas as indicated in Table.

Table 4 indicates that the overall means of the scale areas came at a (high) degree, a mean (3.45), and SD (.44). The aesthetic patriotism area ranked first with a mean (3.60) while economic patriotism ranked last with the mean (3.19) and a moderate degree. This result may be attributed to the positive role that the faculty members play in developing a sense of patriotism in the various areas such as aesthetic and cultural sense which came to a high degree. This result is consistent with the result of $[18,27]$ and differed with [21] which came with a moderate degree. The means and standard deviations of the participants' responses were also calculated on each of the items of each area as shown below:

Table 4. Means and SD for the role of faculty members in the two universities in developing the patriotism among students in descending order

\begin{tabular}{|c|c|c|c|c|c|}
\hline $\begin{array}{c}\text { No. } \\
\text { Areas }\end{array}$ & Areas & *means & SD & Rank & Degree \\
\hline 4 & $\begin{array}{l}\text { Aesthetic } \\
\text { patriotism }\end{array}$ & 3.60 & .76 & 1 & high \\
\hline 1 & $\begin{array}{c}\text { Cultural } \\
\text { patriotism }\end{array}$ & 3.54 & .57 & 2 & high \\
\hline 2 & $\begin{array}{c}\text { Social } \\
\text { patriotism }\end{array}$ & 3.48 & .66 & 3 & high \\
\hline 3 & $\begin{array}{l}\text { Economic } \\
\text { patriotism }\end{array}$ & 3.19 & .46 & 4 & moderate \\
\hline \multicolumn{2}{|c|}{ Overall tool } & 3.45 & .44 & & high \\
\hline
\end{tabular}

- The first area: Aesthetic patriotism:

The means and standard deviations for the items of this field were calculated and the results were as shown in Table 5

Table 5 shows that the means of the items of the first area ranged between (3.43) and (3.76) with a (high) degree. This high result may be attributed to the role of the faculty member in developing students' ability to act rationally, protect the environment from pollution, adhere to public taste in clothing, and to appreciate science and scholars within the country. This is indicated by paragraphs $(4,3,2,5)$ which came at a (high) degree. Finally, paragraph (1) indicates the need for a faculty member to strengthen students' compliance in public places into good behavior such as not causing chaos. This result is consistent with the result of $[18,27]$ but it differed with the result of [21], which came at a moderate degree.

Table 5.Means and SD for the participants' responses on the area the aesthetic patriotism, arranged in descending order.

\begin{tabular}{|c|c|c|c|c|c|}
\hline Items & Items & *Mean & SD & Rank & Degree \\
\hline 4 & $\begin{array}{l}\text { The faculty member encourages students to control personal } \\
\text { emotions. }\end{array}$ & 3.76 & 1.19 & 1 & high \\
\hline 3 & $\begin{array}{l}\text { The faculty member motivates students to keep the } \\
\text { environment clean and protect it from pollution. }\end{array}$ & 3.75 & 1.08 & 2 & high \\
\hline 2 & $\begin{array}{l}\text { The faculty member directs students to adhere to the general } \\
\text { taste of clothing. }\end{array}$ & 3.56 & 1.09 & 3 & high \\
\hline 5 & $\begin{array}{l}\text { The faculty member directs students to appreciate science and } \\
\text { scholars within the country. }\end{array}$ & 3.52 & 1.11 & 4 & high \\
\hline 1 & $\begin{array}{l}\text { The faculty member invites students to remain calm and not to } \\
\text { cause chaos in public places }\end{array}$ & 3.43 & 1.12 & 5 & high \\
\hline & The first area: Aesthetic patriotism & 3.60 & .76 & & high \\
\hline
\end{tabular}


- The second area: the cultural patriotism:

Table 6 that the means for the items of the second area ranged between (2.98-4.00) and with (moderate-high). This result may be attributed, according to the participants' responses, to the role played by the faculty members in guiding students, instilling the values of belonging, and cherishing the heritage and civilization of the country which is indicated in items $(3,5,6)$ that showed a high degree. Paragraph (6), which came to moderate degree, indicates the weak presentation of the faculty member to concepts and attitudes that emphasize the value of the Arab-Islamic heritage. This high result of this area is consistent with the result of $[18,27]$ while it differed with the result of [21] which was moderate.

\section{- The third area: Social patriotism}

Table 7 shows that the mean for the area paragraphs ranged between (2.92) and (3.85) with a degree (moderate-high). This result may be attributed to the role that a faculty member plays in enhancing students' participation in community volunteer work, educating them on how to address rumors, and promoting a culture of respect, peaceful coexistence, and spreading the values of tolerance among members of society. This is indicated by paragraphs $(2,7,1,5)$, which came with a high degree. As for paragraph (6), it indicates the need to reinforce students to appreciate the national social achievements. This large result agreed with the result of $[18,27]$ but it differed with the result of [21], which was moderate.

Table 6. Means and SD for respondents' responses on the items of the cultural patriotism, arranged in descending order

\begin{tabular}{|c|c|c|c|c|c|}
\hline No. & Items & *Mean & SD & Rank & Degree \\
\hline 3 & $\begin{array}{c}\text { The faculty member directs students to cherish the heritage and } \\
\text { civilization of the country. }\end{array}$ & 4.00 & 1.06 & 1 & high \\
\hline 5 & $\begin{array}{c}\text { The faculty member invites students to be culturally aware and open } \\
\text { to others. }\end{array}$ & 3.79 & 1.11 & 2 & high \\
\hline 4 & A faculty member encourages students to participate in national \\
cultural events. & 3.56 & 1.14 & 3 & high \\
\hline 2 & $\begin{array}{c}\text { The faculty member encourages students to respect the customs and } \\
\text { traditions of society. }\end{array}$ & 3.48 & 1.07 & 4 & 5 \\
\hline 1 & $\begin{array}{c}\text { The faculty member invites students to be proud of their national } \\
\text { identity. }\end{array}$ & 3.40 & 1.16 & high \\
\hline 6 & $\begin{array}{c}\text { The faculty member presents to the students, concepts, and attitudes } \\
\text { that emphasize the value of the Arab-Islamic heritage }\end{array}$ & 2.98 & 1.32 & 6 & moderate \\
\hline & The second area: the cultural patriotism & $\mathbf{3 . 5 4}$ & $\mathbf{. 5 7}$ & high \\
\hline
\end{tabular}

Table 7. The mean and SD for the participants' responses on the items of social patriotism, arranged in descending order.

\begin{tabular}{|c|c|c|c|c|c|}
\hline No. & Items & *mean & SD & Rank & Degree \\
\hline 2 & $\begin{array}{c}\text { The faculty member motivates students to participate in community } \\
\text { volunteer work. }\end{array}$ & 3.85 & 1.12 & 1 & high \\
\hline 7 & A faculty member invites students to counter malicious rumors. & 3.67 & 1.17 & 2 & high \\
\hline 1 & $\begin{array}{c}\text { The faculty member enhances students' respect for the other's culture } \\
\text { and peaceful coexistence with it. }\end{array}$ & 3.54 & 1.16 & 3 & high \\
\hline 5 & $\begin{array}{c}\text { The faculty member directs students to adhere to the values of } \\
\text { tolerance among members of society. }\end{array}$ & 3.52 & 1.06 & 4 & high \\
\hline 3 & $\begin{array}{c}\text { A faculty member encourages students to love and defend the } \\
\text { country. }\end{array}$ & 3.44 & 1.11 & 5 & high \\
\hline 4 & A faculty member invites students to maintain national unity. & 3.40 & 1.26 & 6 & high \\
\hline 6 & $\begin{array}{c}\text { A faculty member encourages students to cherish national social } \\
\text { achievements. }\end{array}$ & 2.92 & 1.36 & 7 & moderate \\
\hline & The third area: Social patriotism & $\mathbf{3 . 4 8}$ & $\mathbf{. 6 6}$ & & high \\
\hline
\end{tabular}


- Fourth area: Economic patriotism:

As shown in Table 8 the mean of items of the first paragraphs ranged between (2.93-3.64) with a (high) degree. This result may be attributed to the weak role the faculty member plays in educating students to adhere to financial obligations towards the country, its products, and its properties. As for paragraph (3), which came to a moderate degree, it may be attributed to the weak role of the faculty member in motivating students to rationalize consumption. This high result agreed with the result of $[18$, 27], while it differed with the result of [21], which was moderate.
The results of the second question: Are there statistically significant differences at the level of significance $(\alpha \leq 0.05)$ between the averages of the responses on the role of faculty members in developing the sense of patriotism amongst students at Jadara University and Jerash Al Ahlia University from students' point of view attributed to variables: university, gender, school year and the college. To answer this question, means and standard deviations were calculated for the responses on the study tool according to variables (university, gender, academic year, and college)as shown in Table (9).

Table 8. Means and SD for the participants' responses on the items of the economic patriotism is in descending order

\begin{tabular}{|c|c|c|c|c|c|}
\hline NO. & Items & *mean & SD & Rank & Degree \\
\hline 4 & $\begin{array}{c}\text { The faculty member directs students to abide by financial duties towards the } \\
\text { country. }\end{array}$ & 3.64 & 1.16 & 1 & high \\
\hline 5 & The faculty member encourages students to buy national products. & 3.58 & 1.17 & 2 & high \\
\hline 2 & The faculty member invites students to preserve the country's public \\
properties. & 3.06 & 1.17 & 3 & moderate \\
\hline 1 & $\begin{array}{c}\text { The faculty member directs students to preserve the public money of the } \\
\text { country. }\end{array}$ & 3.01 & 1.17 & 4 & moderate \\
\hline 6 & $\begin{array}{c}\text { The faculty member directs students to appreciate the country's efforts in } \\
\text { economic development in the Kingdom. }\end{array}$ & 2.94 & 1.32 & 5 & moderate \\
\hline 3 & The faculty member encourages students to save and rationalize \\
consumption. & 2.93 & 1.21 & 6 & moderate \\
\hline & The fourth area: Economic patriotism & $\mathbf{3 . 1 9}$ & $\mathbf{. 4 6}$ & moderate \\
\hline
\end{tabular}

Table 9. Mean and SD for the responses, according to the variable (university, gender, academic year, college)

\begin{tabular}{|c|c|c|c|c|}
\hline Variable & Level/categories & Mean & No. & SD \\
\hline \multirow{3}{*}{ University } & Jerash Al Ahlia & 3.39 & 378 & .459 \\
\hline & Jadara & 3.52 & 329 & .405 \\
\hline & Total & 3.45 & 707 & .439 \\
\hline \multirow{3}{*}{ Gender } & Male & 3.39 & 372 & .459 \\
\hline & Female & 3.51 & 335 & .408 \\
\hline & Total & 3.45 & 707 & .439 \\
\hline \multirow{5}{*}{ Year of study } & first & 3.19 & 70 & .281 \\
\hline & second & 3.51 & 183 & .471 \\
\hline & third & 3.39 & 298 & .414 \\
\hline & fourth & 3.59 & 156 & .439 \\
\hline & Total & 3.45 & 707 & .439 \\
\hline \multirow{3}{*}{ College } & Scientific & 3.37 & 299 & .441 \\
\hline & Humanity & 3.50 & 408 & .429 \\
\hline & Total & 3.45 & 707 & .439 \\
\hline
\end{tabular}


Table 9 shows that there are apparent differences between the means of the respondents' responses on each area of the role of faculty members in developing the patriotism sense among students according to the variables (university, gender, school year, and college). To determine the statistical significance of these apparent differences, MANOVA was applied as shown in Table 10.
As indicated in Table 10 there are no differences attributable to the impact of university variables and gender, and that there is a statistically significant difference at the level of statistical significance $(\alpha=0.05)$ for the overall responses on the role of faculty members in developing the patriotism among students according to the variable of the school year. To find out the significance of the differences, Post Hoc tests were made using Scheffé's method.

Table 10. MANOVAof the means of the responses, according to the variable (university, gender, academic year, college)

\begin{tabular}{|c|c|c|c|c|c|}
\hline Variable & SS & Df & MS & F value & P-value \\
\hline University & .151 & 1 & .151 & .859 & .354 \\
\hline Gender & .000 & 1 & .000 & .002 & .962 \\
\hline Year of study & 4.172 & 3 & 1.391 & 7.915 & .000 \\
\hline College & .294 & 1 & .294 & 1.673 & .196 \\
\hline Error & 119.652 & 681 & .176 & & \\
\hline Total & 8535.764 & 707 & & & \\
\hline Modified total & 136.099 & 706 & & & \\
\hline
\end{tabular}

Table 11. MANOVA of the mean of the responses on each area of the role of faculty members in developing the patriotism among students according to the variable (university, gender, academic year, college specialization)

\begin{tabular}{|c|c|c|c|c|c|c|}
\hline Source of variance & Areas & SS & Df & MS & F value & Sig \\
\hline \multirow{4}{*}{$\begin{array}{c}\text { University } \\
\text { Wilks' Lambda value }=.991 \\
\text { Sig. }=.190\end{array}$} & First area: cultural patriotism & .039 & 1 & .039 & .141 & .707 \\
\hline & Second area: social patriotism & 1.469 & 1 & 1.469 & 3.661 & .056 \\
\hline & Third area: economic patriotism & .029 & 1 & .029 & .145 & .703 \\
\hline & Fourth area: Aesthetic patriotism & .018 & 1 & .018 & .036 & .850 \\
\hline \multirow{4}{*}{$\begin{array}{c}\text { Gender } \\
\text { Hoteling's Trace value }=.004 \\
\text { Sig. }=.600\end{array}$} & First area: cultural patriotism & .020 & 1 & .020 & .072 & .788 \\
\hline & Second area: social patriotism & .014 & 1 & .014 & .034 & .854 \\
\hline & Third area: economic patriotism & .110 & 1 & .110 & .545 & .461 \\
\hline & Fourth area: Aesthetic patriotism & .405 & 1 & .405 & .793 & .374 \\
\hline \multirow{4}{*}{$\begin{array}{c}\text { Year of study } \\
\text { Wilks' Lambda value }=.885 \\
\text { Sig. }=.000\end{array}$} & First area: cultural patriotism & 18.448 & 3 & 6.149 & 22.162 & .000 \\
\hline & Second area: social patriotism & 2.202 & 3 & .734 & 1.829 & .140 \\
\hline & Third area: economic patriotism & .428 & 3 & .143 & .709 & .547 \\
\hline & Fourth area: Aesthetic patriotism & 12.430 & 3 & 4.143 & 8.114 & .000 \\
\hline \multirow{4}{*}{$\begin{array}{c}\text { College } \\
\text { Wilks' Lambda value }=.996 \\
\text { Sig. }=.556\end{array}$} & First area: cultural patriotism & .526 & 1 & .526 & 1.895 & .169 \\
\hline & Second area: social patriotism & .108 & 1 & .108 & .269 & .604 \\
\hline & Third area: economic patriotism & .110 & 1 & .110 & .547 & .460 \\
\hline & Fourth area: Aesthetic patriotism & .764 & 1 & .764 & 1.497 & .222 \\
\hline \multirow{4}{*}{ Total } & First area: cultural patriotism & 9066.833 & 707 & & & \\
\hline & Second area: social patriotism & 8848.184 & 707 & & & \\
\hline & Third area: economic patriotism & 7356.361 & 707 & & & \\
\hline & Fourth area: Aesthetic patriotism & 9594.160 & 707 & & & \\
\hline \multirow{4}{*}{ Modified total } & First area: cultural patriotism & 231.378 & 706 & & & \\
\hline & Second area: social patriotism & 303.542 & 706 & & & \\
\hline & Third area: economic patriotism & 148.007 & 706 & & & \\
\hline & Fourth area: Aesthetic patriotism & 411.269 & 706 & & & \\
\hline
\end{tabular}


By examining Table 11, we can notice that:

- University variable: the results of the study showed that there were no statistically significant differences at the level of statistical significance $(\alpha=0.05)$ on all the areas of the role of faculty members in developing the patriotism among students according to the university variable. This indicates that the type of university is not a criterion in developing the national sense among students, as the universities, in general, seek to develop and strengthen the national sense of students. No evidence has emerged from any study.

- Gender variable: The results show that there were no statistically significant differences at the level of statistical significance $(\alpha=0.05)$ on all areas of the role of faculty members at the universities in developing the national sense among students attributed to the gender variable. This result may be attributed to the fact that the faculty members of both genders are keen to provide knowledge and develop the national sense of students in various areas of the tool, and this result differed with the result of [20].

- College variable: there were no statistically significant differences attributable to the variable of the college's specialization. This result may be attributed to the fact that the college variable is not a criterion in developing and enhancing the national sense of students, as all members of the faculty in various colleges seek to enhance the sensory awareness of students, and this result agreed with the result of Safwa result.

- There were no statistically significant differences attributable to the variable of the year of study, except for the first and fourth fields. To identify the significance of the differences, the Post Hoc test was made using the Scheffe method and the results were as follows:

Table 12. The Post Hoc/ Scheffe method for the response on the role of faculty members in developing the total sense of patriotism according to the variable of the academic year of study

\begin{tabular}{|c|c|c|c|c|}
\hline Areas & $\begin{array}{c}\text { Year of } \\
\text { study (I) }\end{array}$ & $\begin{array}{c}\text { Year of } \\
\text { study (J) }\end{array}$ & MD & Sig \\
\hline \multirow{3}{*}{$\begin{array}{c}\text { Cultural } \\
\text { patriotism }\end{array}$} & first & second & $-.67\left(^{*}\right)$ & .000 \\
\cline { 2 - 5 } & & third & $-.36\left(^{*}\right)$ & .000 \\
\cline { 2 - 5 } & & fourth & $-.66\left(^{*}\right)$ & .000 \\
\hline \multirow{3}{*}{$\begin{array}{c}\text { Aesthetic } \\
\text { patriotism }\end{array}$} & first & second & $-.58\left(^{*}\right)$ & .000 \\
\cline { 2 - 5 } & & third & $-.39\left(^{*}\right)$ & .001 \\
\cline { 2 - 5 } & & Fourth & $-.77(*)$ & .000 \\
\hline
\end{tabular}

Table 12 shows that there are differences between the first, third, and fourth categories, on the other hand, and for the benefit of each of the second, third, and fourth categories. This result may be attributed to the need of this group for more awareness and development about the sense of patriotism in its various areas aesthetic, social, cultural, and psychological.

\section{Recommendations}

Considering the results, the researchers recommend the following:

- Enhancing the role of faculty members in developing and educating students of various years of study on the importance of strengthening the national sense and its positive role which will reflect on them and the security of their country, stability, and self-affirmation.

- Enhancing the role of faculty members in educating students to adhere to financial obligations towards the country, its products, and its properties, and how to care for the nation's property

- Conducting more studies on how to develop the students' national sense using different variables.

\section{Conclusions}

By examining the results which came with a high degree, we can realize the positive role of the faculty members in Jordanian universities in developing patriotism among students in various areas such as the aesthetic and cultural sense of patriotism. The results also showed the need to enhance the economic patriotism among the students in Jordanian universities.

- Aesthetic patriotism: its high degree indicates the significant role that a faculty member plays in developing students' self-control, their interest in the environment, their adherence to public taste in clothing, and their appreciation to scientists and scholars.

- Cultural patriotism: which came in the second place, this indicates the universities awareness of the importance of guiding students, inculcating the values of belonging and cherishing the heritage and civilization of the country, and helping them to be culturally open as this will positively reflect on their thinking and respect to the others customs and traditions.

- Social patriotism: it came in the third place, which means that universities realize the importance of community volunteer work, educating students on how to counter rumors, and promoting a culture of respect, peaceful coexistence, and commitment to the values of tolerance among members of society that enhance their national sense.

Finally, the economic patriotism: came in the last rank with a moderate degree, which indicates the need to continuously reinforce students to adhere to the financial duties towards the country, its products, and its properties, and how to take care of the nation's properties. 


\section{REFERENCES}

[1] Muslim, A. (2006). Sahih Muslim, first edition, taken care of by: Muhammad al-Faryabi, Riyadh: Dar Taibah.

[2] Hamayel, A. (2011). The role of (FM) radio in promoting the national patriotism of university students, "The University of the Middle East is a model." Unpublished MA thesis, Middle East University, Jordan.

[3] Al-Enzi, A. (2015). The role of school administration in developing citizenship values for high school students. Journal of Gulf and Arabian Peninsula Studies, 4 (158).

[4] Batha, A. (2011). Feeling of Arab national and national belonging and its relationship to personal hardness among male and female students of the College of Education: Clinical Psychometric Study. Ain Shams University conference, the sixteenth annual conference.

[5] Halpern, D., John, P., and Morris, Z. (2002). Before the Citizenship order: A survey of citizenship education practice in England. Journal of Education Policy, 17(2), 217 -228 .

[6] Mohammad, N. (2010). Strengthen Patriotism through Education. Malaysian Journal of Youth Studies, 8(4), 1-24.

[7] Lushinkov, I.D. (2014). The systemic technique of studying the patriotic upbringing: a methodological guideline. Vologda: VIRO (VIDE).

[8] Schlabach, G. W. (2000). Acquiring a sense of history. Retrieved: March 25, 2020, from: http://www.victorserge.Net.

[9] Ben, S. (2007). Civic virtue out of necessity patriotism and democratic education, Theory and Research in Education, $5(1), 41-59$

[10] Schatz, R.T., Staub, E., \& Lavine, H. (1999). On the varieties of national attachment: Blind versus constructive patriotism. Political Psychology, 20(1), 151-174.

[11] Mohd, H., \& Rohani, S. (2004). Patriotism and Belonging. Malaysian Journal of Youth Studies, 8(4), 1-24.

[12] Mendoza, P; Suarez, J; Bustamante, E. (2016). Sense of Community in Student Retention at a Tertiary Technical Institution in Bogota: An Ecological Approach. Community College Review; Oct 2016; 44, 4; Education Database. 286-314.

[13] Al-Shammari, R.. (2018). The role of faculty members in enhancing the values of moderation among students of Hafr Al-Batin University in Saudi Arabia from the students' point of view. Journal of Educational and Psychological Sciences, 16 (2), 47-63.

[14] Quinn, J. (2005). Belonging in a learning community: The re-imagined university and imagined social capital. Studies in the Education of Adults, 37(1), 4-17.

[15] Al- Jazzar, N. (2007). A proposed enrichment program in history for high school students in the first year of secondary school and its effect on developing their historical sense. The Journal of Social Studies, (11), 67-114.
[16] Huwaidi, A,.and Al-Hawamdi, S. (2016). Educational curricula and their role in the development of citizenship. Al-Shaheed Hama Lakhdar University, Journal of Social Studies and Research, 15, 52-60.

[17] Olsen, L. (2009). Since of place in Museum public programming: Three case studies. Journal of Museum Education, 34(3) 293-300.

[18] Al-Najjar, B. (2013). The role of higher education institutions in developing the national sense of their students. Research submitted to the first scientific conference at the College of Science and Technology, Khan Yunis, Palestine.

[19] Al-Khawaldeh, T. (2013). The role of a faculty member in Jordanian universities in developing the values of citizenship from the viewpoint of students, University of Jordan, Studies of Educational Sciences, 40 (3), 1160-1180.

[20] Al-Hakami, I. (2009). Professional competencies required for a university professor from the viewpoint of his students and their relationship to some variables. The Journal of the Arab Gulf Letter, 9 (2), 257-278.

[21] Khazaleh, A. (2018). The role of a faculty member in Jordanian universities in educating students about the dangers of terrorist and extremist thought and developing their national sense from the perspective of its students. International Journal of Educational Sciences, 1 (3), 229-264.

[22] Suwaidan, B. Al-Qaoud, I, and Obaidat, H. (2018). The role of colleges of education in Saudi universities in promoting the values of citizenship among students from the viewpoint of faculty members and students. The University of Jordan, Studies of Educational Sciences, 45 (4), 567-587.

[23] Nair, S., \& Sinasamy, R. (2017). Patriotism among Secondary School Students and Its Relationship with their Interests towards Learning. Asian Journal of Education and Training, 3(2), 110-117.

[24] Ozturk, F., Malkoc, S., \& Ersoy. (2016). Patriotism as Perceived by Social Studies Teachers: An Outlook on the Individual, Society, and Education. PAU EgitFakDerg, 4(1), 205-218.

[25] Al-Thabiti, M,.and Hussein, M. (2015). The role of the university administration in developing the values of citizenship for Tabuk University students. Taibah University Journal for Educational Sciences, 11 (3) 349-365.

[26] Al-Shafei, S,. Al-Fatlawi A, Al-Daini, J. (2014). Strategies used by faculty members in developing the values of citizenship among students of the departments of history and the Arabic language, a comparative study. Dawat Journal for Linguistic and Educational Studies and Research, 213-253

[27] Al-Daw, M. (2013). The affiliation of the homeland to the university youth and its relationship with the motive for academic achievement: a field study on students of the Faculties of Education - University of Bakht al-Rida. Bakht al-Ruda University scientific journal, seventh edition, 35-51. 